\title{
Enhancement of energy generation efficiency in industrial facilities by SOFC - SOEC systems with additional hydrogen production
}

Vialetto, Giulio; Noro, Marco; Colbertaldo, Paolo; Rokni, Masoud

Published in:

International Journal of Hydrogen Energy

Link to article, DOI:

10.1016/j.ijhydene.2018.08.145

Publication date:

2019

Document Version

Peer reviewed version

Link back to DTU Orbit

Citation (APA):

Vialetto, G., Noro, M., Colbertaldo, P., \& Rokni, M. (2019). Enhancement of energy generation efficiency in industrial facilities by SOFC - SOEC systems with additional hydrogen production. International Journal of Hydrogen Energy, 44(19), 9608-9620. https://doi.org/10.1016/j.ijhydene.2018.08.145

\section{General rights}

Copyright and moral rights for the publications made accessible in the public portal are retained by the authors and/or other copyright owners and it is a condition of accessing publications that users recognise and abide by the legal requirements associated with these rights.

- Users may download and print one copy of any publication from the public portal for the purpose of private study or research.

- You may not further distribute the material or use it for any profit-making activity or commercial gain

- You may freely distribute the URL identifying the publication in the public portal 


\title{
Enhancement of energy generation efficiency in industrial facilities by SOFC - SOEC systems with additional hydrogen production
}

\author{
Giulio Vialetto ${ }^{\mathrm{a}}$, Marco Noro ${ }^{\mathrm{a}}$, Paolo Colbertaldo ${ }^{\mathrm{b}}$, Masoud Rokni $^{\mathrm{c}}$ \\ aDepartment of Management and Engineering, University of Padova \\ Stradella San Nicola, 3, 36100 Vicenza, Italy \\ e-mail: giulio@giuliovialetto.it; marco.noro@unipd.it \\ ${ }^{\mathrm{b}}$ Department of Energy, Politecnico di Milano \\ Via Lambruschini 4A, 20156 Milan, Italy \\ e-mail: paolo.colbertaldo@polimi.it \\ ${ }^{c}$ Department of Mechanical Engineering, Technical University of Denmark \\ Copenhagen 2800, Denmark \\ e-mail: $\underline{\text { mr@mek.dtu.dk }}$
}

*Corresponding author. Tel.: +39 0444 998704; Fax: +390444998884

e-mail address: marco.noro@unipd.it

\begin{abstract}
Industry is one of the highest energy consumption sector: some facilities like steelworks, foundries, or paper mills are highly energy-intensive activities. Many countries have already implemented subsidies on energy efficiency in generation and utilisation, with the aim of decreasing overall consumption and energy intensity of gross domestic product. Meanwhile, researchers have increased interest into alternative energy systems to decrease pollution and use of fossil fuels. Hydrogen, in particular, is proposed as a clean alternative energy vector, as it can be used as energy storage mean or to replace fossil fuels, e.g. for transport.

This work analyses the re-vamping of the energy generation system of a paper mill by means of reversible solid oxide cells (RSOCs). The aim is not only to increase efficiency on energy generation, but also to create a polygeneration system where hydrogen is produced. Application on a real industrial facility, based in Italy with a production capacity of $60000 \mathrm{t} / \mathrm{y}$ of paper, is analysed. First, the current energy system is studied. Then, a novel system based on RSOC is proposed. Each component of the systems (both existing and novel) is defined using operational data, technical datasheet, or models defined with thermodynamic tools. Then, the interaction between them is studied. Primary energy analysis on the novel system is performed, and saving with respect to the current configuration is evaluated. Even if the complexity of the system increases, results show that saving occurs between 2 and $6 \%$. Hydrogen generation is assessed, comparing the RSOC integrated system with proton exchange membrane (PEM) electrolysis, in terms of both primary energy and economics. Results exhibit significant primary energy and good economic performance on hydrogen production with the novel system proposed (hydrogen cost decreases from $10 € / \mathrm{kg}$ to at least $8 € / \mathrm{kg})$.
\end{abstract}




\section{KEYWORDS}

Energy-intensive industry; energy efficiency; primary energy saving; hydrogen; SOFC/SOEC.

\section{INTRODUCTION}

The growing attention to climate change and the subsequent need to shift towards low-emissions energy systems affect all the fields where energy conversion and utilisation is involved. Indeed, the strong decarbonisation objectives $(80 \%$ greenhouse gas emissions reduction by 2050 against 1990 level [1]) requires cooperation by power generation and consumptions as well as by transport, agriculture, and industry. Evolution of the energy system will involve the development of multiple energy vectors and therefore increased integration, so that electricity and natural gas will be paired with clean fuels such as renewable hydrogen and biofuels [2-3], also considering transport systems [4].

Many processes in the industrial sector are highly energy intensive, so that energy efficiency measures and innovative conversion solutions are deeply investigated for both environmental protection [5] and operational costs reduction [6]. Advantages can be evaluated in either purely technical (energy saving) or techno-economic (cost reduction) terms. Typical examples are industrial applications where high energy flows are treated, like metals and plastic manufacturing [7], or wood processing [8]. A number of studies has investigated glass production and the potential for energy performance improvement with different integrated processes [9], [10]. Energy analyses on cast iron foundries have been developed that investigate the energy consumption and propose system improvements to decrease and control it [11], [12], [13]. At another level of analysis, Smolek et al. [14] have looked at a generic production plant and have proposed a simulation approach based on decomposing the whole building into modules corresponding to different processes, in order to analyse the energy performance separately and then investigate the interconnection effects. In general, potential for reduction of energy consumption exists when diverse energy vectors are needed by the same process or by contiguous devices in the same facility. In the simplest cases, combined generation of heating/cooling and power [15] easily leads to energy savings. For example, in [16] the development of a simulation model of a combined generation of heating/cooling and power system of $630 \mathrm{~kW}$ size applied in an industrial case study has been presented. An ASPEN model has been developed for the simulation of a gasificationSOFC plant with a downdraft gasification process from lignocellulosic biomass. The results of the model have been used to set a model of the whole CCHP system in TRNSYS environment. The dynamic simulations results showed that the primary energy consumption using the trigeneration system could be reduced of about $50 \%$ with respect to a traditional system with separate energy production.

The contemporary request of heat and electricity characterizes the pulp and paper industry, which thus opens to innovative process integration for energy efficiency improvement [17], [18]. Focusing on the final step, i.e. paper production in paper mills, two energy vectors are involved: heat to satisfy the need of drying the mid-products, and electrical power to drive the motors. The use of combined heat and power (CHP) units in paper mills is a known strategy, typically implemented with conventional internal combustion engines or steam turbines [19], [20]. Decarbonisation strategies have been investigated considering the use of renewable biomass or waste from the 
facility itself as sources as well as the introduction of carbon capture technologies [21], [22]. In [23], a feasibility study of the implementation of different cogeneration options to a paper mill to evaluate their energy saving potentials and economic benefits has been described. The investigated systems are gas turbine, steam turbine and combined cycle cogeneration options evaluated and compared based on energy utilisation factor and annualized life cycle cost analysis.

In the field of multi-energy systems, hydrogen has been studied lately as an alternative for both power generation and storage. Canan et al. [24] have studied hydrogen production from renewable and non-renewable sources to assess environmental impact, production costs, energy and exergy efficiency of the different methods. Astiaso Garcia et al. [25] have surveyed and analysed potential of hydrogen as energy storage systems in EU countries to reduce energy fluctuations and possible negative effects due to an increase of renewable sources share in power generation. Guandalini $e t$ al. [26] have investigated the use of Power-to-Gas systems coupled with wind farms to improve dispatchability. Castellani et al. [27] have studied the use of hydrogen produced with renewable energy for flue gas treatment to produce methane and ammonia, in order to reduce carbon footprint of the process. Posdziech et al. [28] have described three application examples where large scale prototype of a reversible solid oxide cell (RSOC) technology has been installed: 1) A power-topower electricity storage based on hydrogen, 2) a RSOC unit installed in an iron and steel works, and 3) a pressurized SOEC prototype integrated with a methanation unit. In a wider vision, Dodds et al. [29] have analyzed the need to include hydrogen and fuel cell heating technologies in future scenario analyses, and for policymakers to take into account the full value of the potential contribution of hydrogen and fuel cells to low-carbon energy systems.

The aim of this research article is to analyse the energy generation system of a paper mill that involves high electricity and heat demands, and to investigate possible alternative systems to increase overall efficiency by the use of hydrogen. As the main novelty of this study, the adoption of a solid oxide fuel cell / solid oxide electrolyser cell (SOFC/SOEC) system is proposed, substituting of part of the existing set of cogenerators. This introduces an additional hydrogen production as a result of the need to balance the mismatch of heat-to-power ratios between energy production and consumption. As a matter of fact, this enlarges the plant activity beyond paper production, exploiting the inherent capability of managing high-temperature flows and bringing it into the field of multi-energy integrated systems, which are expected to become more and more relevant in the clean energy future.

Section 2 describes the current system configuration, the operating strategies, and the models used to reproduce the various components' behaviour. Section 3 details the proposed novel system structure, which comprises innovative devices whose representation exploits existing tools [30]. In Section 4, the behaviour of the new units is simulated, and results are discussed together with the comparison of options. Finally, Section 5 presents the main conclusions of the study.

\section{OVERVIEW OF THE CURRENT SYSTEM}

The industrial facility under consideration is a paper mill located in the North-East of Italy. It produces paper with a weight between $40 \mathrm{~g} / \mathrm{m}^{2}$ and $500 \mathrm{~g} / \mathrm{m}^{2}$, and it is equipped with two paper production lines with an annual capacity of 60000 t/year. Figure 1 represents the scheme of one production line within the paper mill, highlighting the different processes involved. First, pulp is mixed with water and raw materials (e.g., kaolinite, a type of clay) in the headbox. Then, the 
obtained pre-product is sent to the wet-press section where rollers press it to start removing water from the pulp. Next, in the drying section, heated rollers and felts further decrease water content and thickness of the pre-product down to production specifications. Each production line consumes electricity for motors (each roller has an independent one) and vacuum pumps (felts uses vacuum instead of heat for drying), while heat is required to heat up rollers (steam is generally used). In some cases, natural gas-fired dryer are used within the drying section.

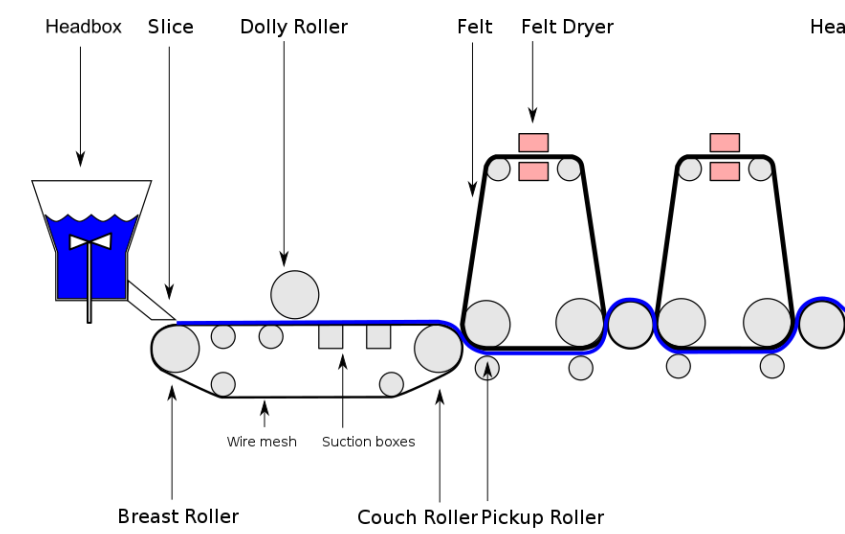

Wet End

Wet Press Section

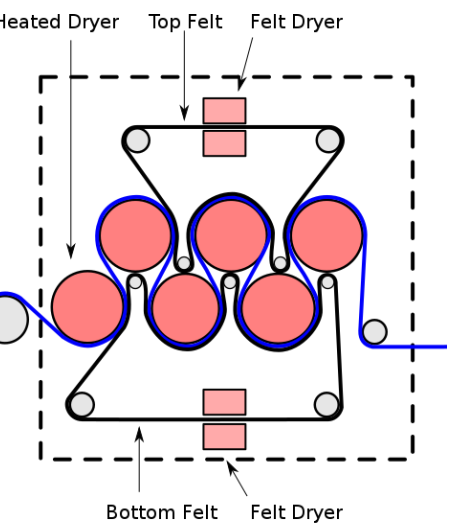

Dryer Section

Figure 1 - Schematic representation of a paper production line.

After the economic crisis of 2008, the drop in paper request reduced the production rate significantly. Due to the high start-up time (typically half to one day), a paper production line must run continuously, with the workers active on a three-shift basis. In order to match the lower paper request to the plant capacity, the production cycles have been organised in series of some full-load days followed by days off, e.g. each production line is run continuously for 6 days and then it is switched off for 3 days. Figure 2 represents the current organisation of the production. In Case 1, only line 1 works; in Case 2, only line 2 works; in Case 1+2, both lines 1 and 2 are in operation. One of the consequences of this production plan is that the total operating time is uniformly divided into three situations: for one third of the time all the paper production lines work, for another one third only Line 1 works, and for the last one third only Line 2 is in operation. As electricity and steam consumptions are generally variable with time, in this work a representative average value of electricity and heat consumption is considered for each case, extracted from real data.

\begin{tabular}{|l|c|c|c|c|c|c|c|c|c|}
\hline & Day 1 & Day 2 & Day 3 & Day 4 & Day 5 & Day 6 & Day 7 & Day 8 & Day 9 \\
\hline Line 1 & & & & & & & & & \\
\hline Line 2 & & & & & & & & & \\
\hline Case & Case 1 & Case 1+2 & Case 1+2 & Case 2 & Case 2 & Case 2 & Case 1+2 & Case 1 & Case 1 \\
\hline
\end{tabular}

Figure 2 -Production organisation of the paper mill considered.

As discussed in Section 1, the considerable amounts of electricity and steam required by the industrial process suggests the adoption of a cogeneration system. In the current configuration, the industrial facility has two cogeneration units. The oldest one is based on a natural gas-fired steam generator (installed in the ' 70 s to substitute the previous coal-fired unit), coupled to two steam turbines (still the original ones first installed in the '40s). The newest cogeneration unit (installed in 
2013) features an internal combustion engine (ICE) with heat recovery. Figure 3 represents the overall energy system: both the ICE and the steam turbines discharge steam at the same thermodynamic conditions $\left(235{ }^{\circ} \mathrm{C}\right.$ and $280 \mathrm{kPa}$, as required by the process), and generate electricity. Steam is used in the paper production process mainly to heat up rollers, and it returns to the ICE and the steam generator as condensed water at a temperature of $80{ }^{\circ} \mathrm{C}$ and atmospheric pressure. Both the steam generator and the ICE use natural gas as fuel.

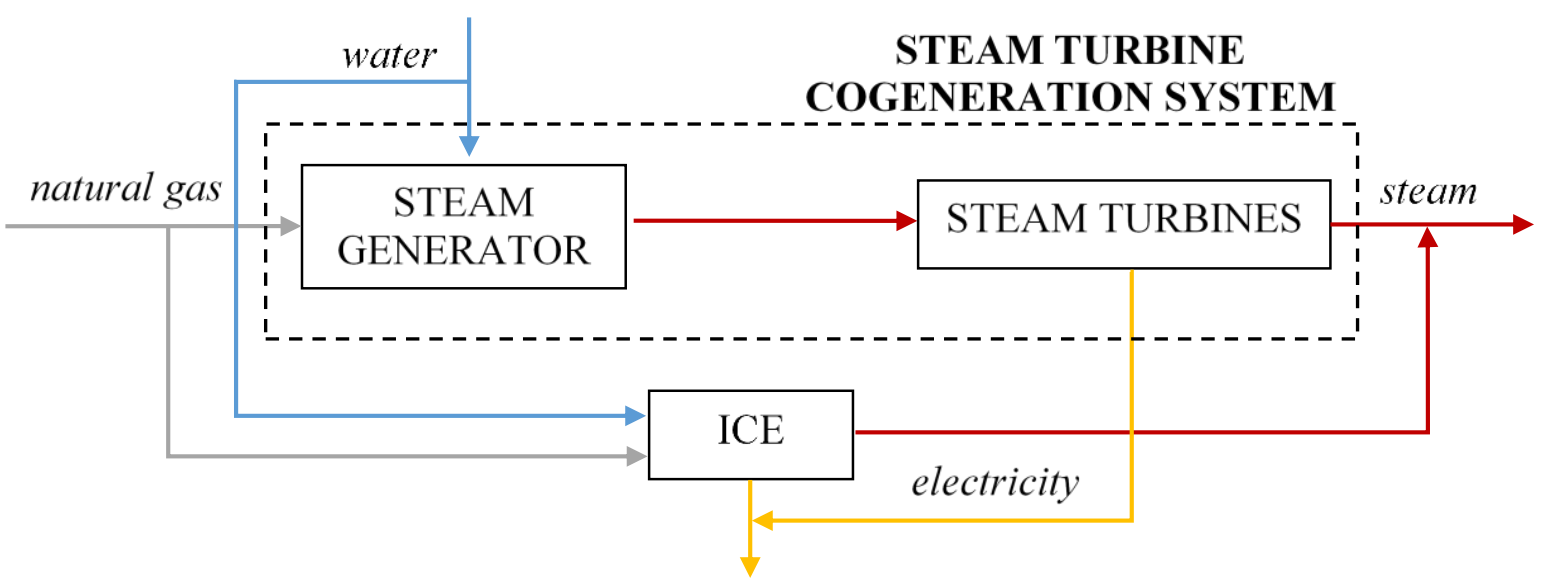

Figure 3-Overview of the cogeneration system with the main equipment and energy flows. Grey flows are natural gas, blue flows are water, red flows are steam, and yellow flows are electricity.

\subsection{Steam turbine cogeneration system}

The steam turbine cogeneration system is composed by a steam generator, two steam turbines, and a thermal user (the paper drying process) that also acts as condenser (Figure 3). The steam generator is fired by natural gas and releases steam at $420{ }^{\circ} \mathrm{C}$ and 35 bar $(3500 \mathrm{kPa})$. The steam turbines expand the fluid, thus generating power while decreasing the pressure from 35 bar to 2.8 bar, which is the pressure required by the paper dryer cylinders. During the expansion process, the temperature decreases from $420{ }^{\circ} \mathrm{C}$ to $235{ }^{\circ} \mathrm{C}$. The requested steam mass flow rate varies according to the number of paper machines operating. Steam turbines operation depends on the steam flow rate required for the paper production process: turbine 1 is used when steam generation is between 5 ton $/ \mathrm{h}$ and $21 \mathrm{ton} / \mathrm{h}$, turbine 2 is used when steam generation is higher. Both steam turbines are more than 50 years old and, even with proper annual maintenance, low performances are expected. In the present work, the steam generator and the turbines are modelled by means of characteristic curves that link fuel demand, electrical generation, and steam mass flow rate. The curves are obtained via mathematical regression from operational data collected in recent years. The information provided by the company about the turbines includes regression curves, so these are used for the analysis directly as given. For the steam generator performance, the curve is obtained from the provided measured values via numerical regression. Figure 4 represents data and curve of natural gas consumption as a function of generated steam mass flow rate (ton/h). The natural gas flow rate $\left(\mathrm{m}^{3} / \mathrm{h}\right)$ is converted into energy consumption (MW) using a reference lower heating value (LHV) of natural gas equal to $9.91 \mathrm{kWh} / \mathrm{m}^{3}$. Equations (1), (2), and (3) in Table 1 describe each component with a suitable expression, where $\dot{m}_{\text {steam }}$ is the mass flow rate of the steam (ton/h), Fuel $l_{\text {cons,ST }}$ is 
the natural gas consumption of the steam generator (MW), and $P_{S T}$ is the electric power generated by the turbine $(\mathrm{kW})$.

\section{STEAM GENERATION}

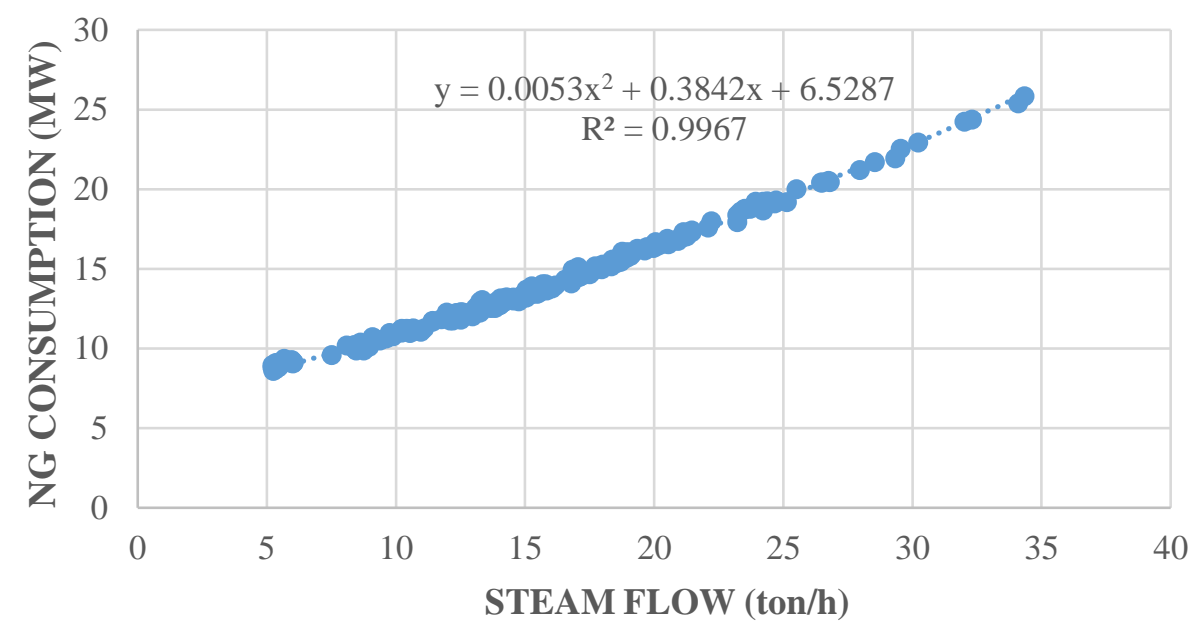

Figure 4 - Data sampling of steam generator and regression.

\begin{tabular}{|c|c|c|}
\hline Component & Equation & Condition \\
\hline \multirow{2}{*}{ Steam generator } & Fuel $_{\text {cons }, S T}=0.0053 * \dot{m}_{\text {steam }}^{2}+0.3842 * \dot{m}_{\text {steam }}+$ & 5 ton $/ \mathrm{h}<\dot{m}_{\text {steam }}<35$ ton $/ \mathrm{h}$ \\
\hline Turbine 1 & $6.5287 \quad(1)$ & 5 ton $/ \mathrm{h}<\dot{m}_{\text {steam }}<21$ ton $/ \mathrm{h}$ \\
\hline Turbine 2 & $P_{S T}=0.0007 * \dot{m}_{\text {steam }}+6.3908 \quad(2)$ & $\dot{m}_{\text {steam }} \geq 21$ ton $/ \mathrm{h}$ \\
\hline
\end{tabular}

Table 1 -Mathematic description of each component of the steam turbine cogenerator.

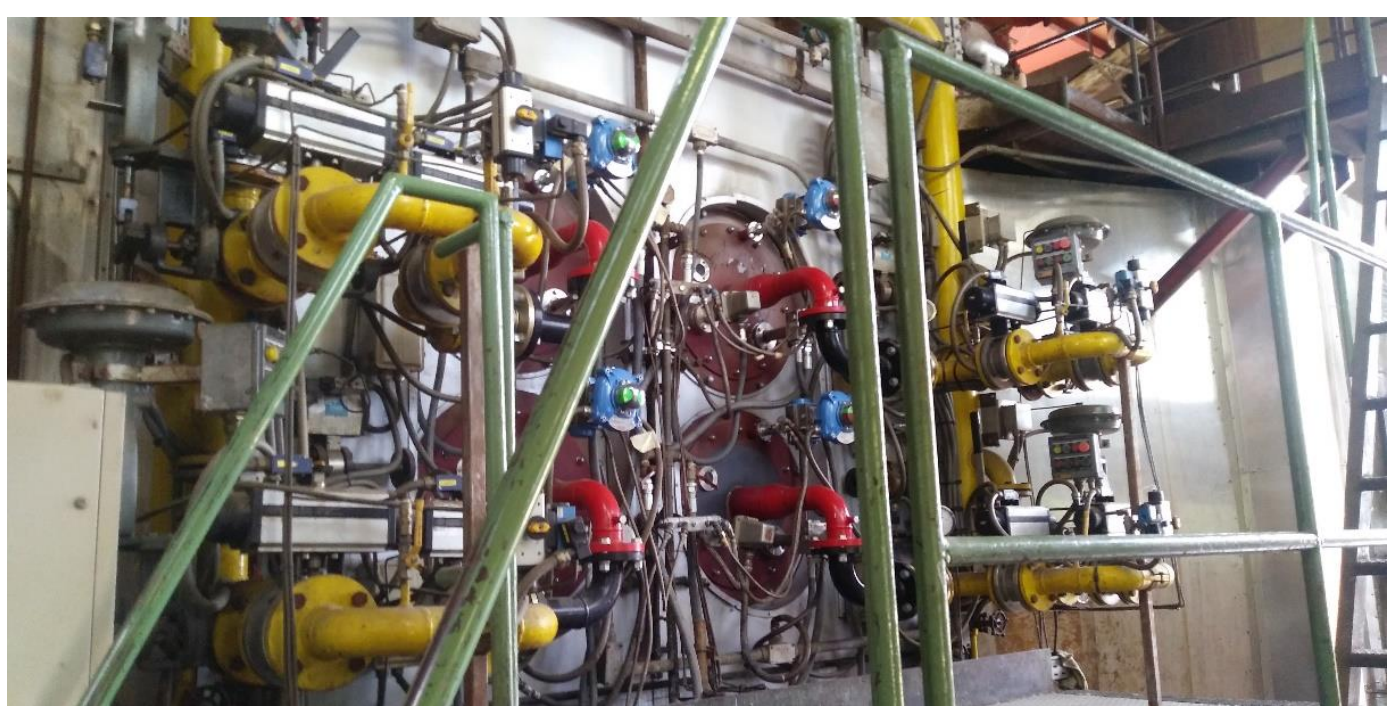

Figure 5 - Steam generator, photo of natural gas burners 


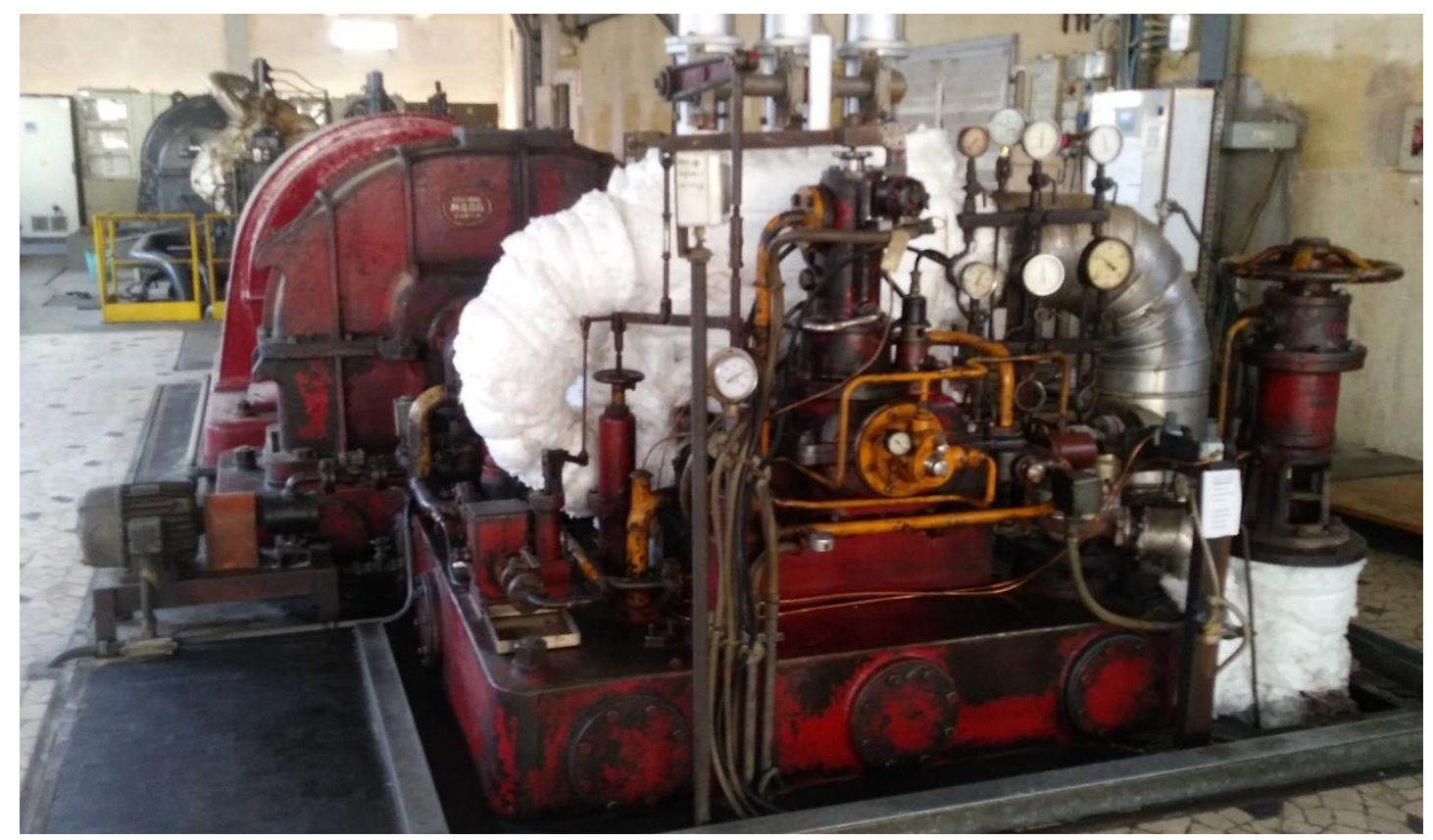

Figure 6-Photo of the existing steam turbines (turbine 1 in front, turbine 2 behind).

\subsection{Internal combustion engine cogenerator}

In the beginning of 2013, the company decided to increase its energy generation capacity, both electricity and heat, adding an ICE fuelled by natural gas with a nominal electric power of $4.3 \mathrm{MW}$. Heat recovery from exhaust gases allows producing steam at the same pressure and temperature of the turbines discharged steam $\left(235^{\circ} \mathrm{C}, 3.5 \mathrm{bar}\right)$. It is possible also to recover heat from the engine cooling water and the intercooler, but this heat is available at low temperature, so it cannot be used for steam generation purposes. In some very limited periods of the year (typically during winter), such low-temperature heat is used for space heating and/or for auxiliaries, anyway for most of the time it is dissipated using dry coolers. Table 2 summarises main ICE nominal parameters. The performance is simulated under different operating conditions based on data taken from its technical datasheet. ICE could work at partial load down to $40 \%$ of the nominal electric power.

\begin{tabular}{|l|r|}
\hline \multicolumn{1}{|c|}{ Parameter } & \multicolumn{1}{c|}{ Value } \\
\hline Nominal electric power & $4.3 \mathrm{MW}$ \\
\hline Nominal fuel consumption & $10.07 \mathrm{MW}$ \\
\hline Steam outlet temperature & $235{ }^{\circ} \mathrm{C}$ \\
\hline Steam outlet pressure & $3.5 \mathrm{bar}(350 \mathrm{kPa})$ \\
\hline Nominal electric efficiency & $42.7 \%$ \\
\hline Nominal thermal efficiency & $44.1 \%$ \\
\hline
\end{tabular}

Table 2 - ICE nominal parameters.

\section{THE NOVEL SYSTEM}


Cogeneration of heat and power has already been implemented in paper mills (and industrial facilities in general) for decades by means of different technologies: ICEs, steam turbines, and gas turbines are the most common options. In this study, fuel cells are proposed for the revamping of the energy generation system within a paper mill.

Considering the facility described in Section 2, the steam turbines are the units under discussion for modification or substitution in order to improve the energy performance, as they feature very low efficiency. In particular, this work adopts solid oxide fuel cells (SOFCs) as alternative cogeneration units, combined with solid oxide electrolysis cells (SOECs) to recover excess power generation when the heat-to-power ratio impose to over-generate electricity to satisfy the heat demand. This is likely to occur not rarely, due to a SOFC heat-to-power ratio very different from the steam turbine one. The rationale of the proposed concept is the high efficiency of the SOFC systems as well as the already proven capability of the facility to manage high-temperature flows. Moreover, this change allows the paper mill to enlarge its sector of activity, entering into the field of multi-energy systems. Indeed, the expected net hydrogen production could be exploited directly as fuel, thus reducing the natural gas consumption, or be addressed to an external market, e.g. hydrogen for mobility.

This section describes the single components and details their interaction, defining the modelling approach. Section 4 will then present the integration of the SOFC-SOEC system with the whole system, and study the system operation.

\subsection{SOFC}

The main advantages of solid oxide fuel cells for combined heat and power generation are the high electrical efficiency on energy conversion, and the availability of heat at high temperature (over 800 C). On the other hand, SOFCs present some disadvantages, mainly related to the high operating temperature: for example, long start-up time and more thermal stresses than other fuel cell types. In the application considered here, these drawbacks are less relevant because:

- start-up time of a paper production line is long as well, up to be comparable to that of a SOFC;

- thermal stresses can be avoided thanks to the possibility of keeping SOFC energy generation quite constant, as heat and electricity consumptions of the production lines do not vary significantly once they are set up.

The SOFC system here proposed has been previously studied by one of the authors with the aim of electricity generation and steam production, e.g. in a hybrid power plant with a bottoming steam turbine cycle [31]. A model of the SOFC system was defined and simulated using the Dynamic Network Analyser software (DNA), a tool developed at the Technical University of Denmark (DTU) [30] [31]. Figure 7 represents the layout of the SOFC system. The fuel proposed is natural gas from grid, so a desulphurizer and a catalytic partial oxidizer (CPO) are required to avoid sulphur poisoning and to crack heavy hydrocarbons, respectively. However, it is relevant to remind that SOFCs can use not only natural gas, but also a mixture of natural gas and hydrogen. Table 3 summarizes the parameters of SOFC system used for the simulation. 


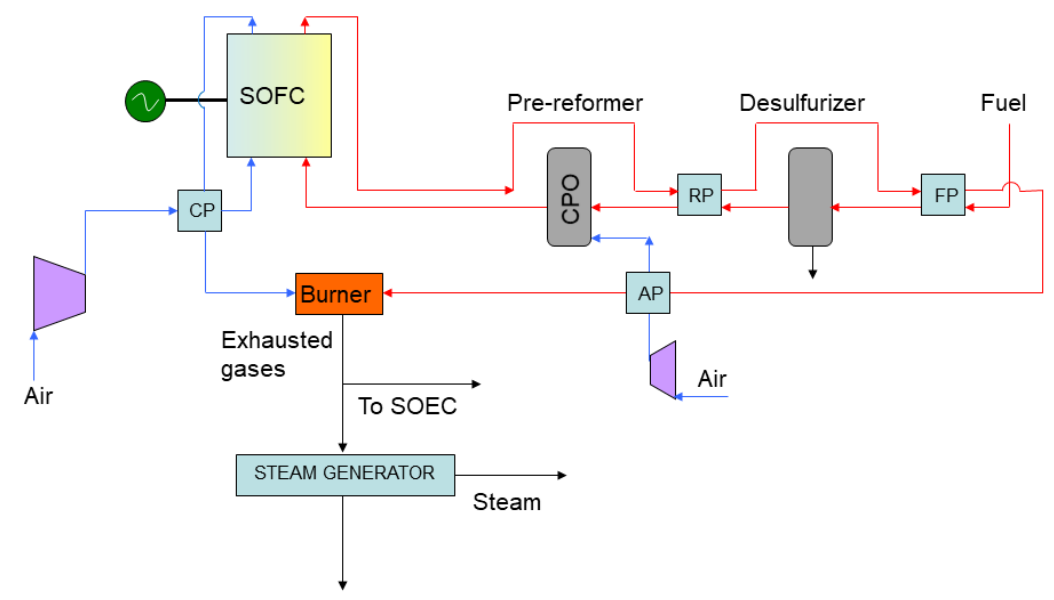

Figure 7 -SOFC system layout. CP (cathode preheater), FP (fuel preheater), AP (air preheater) and RP (reformer preheater) are heat exchangers. Steam generator (STEAM GENERATOR) uses exhaust gases to generate steam. A part of exhaust gases can be fed to the SOEC system.

\begin{tabular}{|l|r|}
\hline \multicolumn{1}{|c|}{ Parameter } & \multicolumn{1}{c|}{ Value } \\
\hline Stack nominal electric power & $100 \mathrm{~kW}$ \\
\hline Electric efficiency (at 90 \% of nominal electric power) & $52.7 \%$ \\
\hline H/P ratio (at 90\% of nominal electric power) & 0.842 \\
\hline Exhaust gases temperature & $1330^{\circ} \mathrm{C}$ \\
\hline
\end{tabular}

Table 3 - SOFC system parameters.

\subsection{SOEC}

To produce hydrogen, SOECs require both electricity and heat. In particular, the latter is necessary to generate high-temperature steam from water to be fed as reactant. Operation of the SOEC considered in this work is also obtained by simulation with the tool DNA from DTU [30], whose features are described in Section 3.1. Figure 8 represents the layout considered: HEX1 and HEX2 are two heat exchangers that cool hydrogen and oxygen, respectively, after they are produced within the SOEC, while preheating water to obtain steam at the required working condition. With the aim of cooling the hydrogen produced as much as possible, inlet water is heated first by HEX1 and then by HEX2. In fact, as hydrogen requires to be compressed, a lower temperature helps reducing the power consumption for compression. HEX3 uses exhaust gases from SOFC to heat the steam up to the SOEC working temperature. Product gases (hydrogen and oxygen) are discharged after SOEC stack at $750{ }^{\circ} \mathrm{C}$, while inlet water has a temperature of $25^{\circ} \mathrm{C}$. Without heat recovery performed by HEX1 and HEX2, HEX3 would exchange a higher thermal power, and it would require a higher exhaust gases flow rate to reach operating temperature, thus increasing the heat demand by SOEC. Table 4 resumes SOEC parameters. 


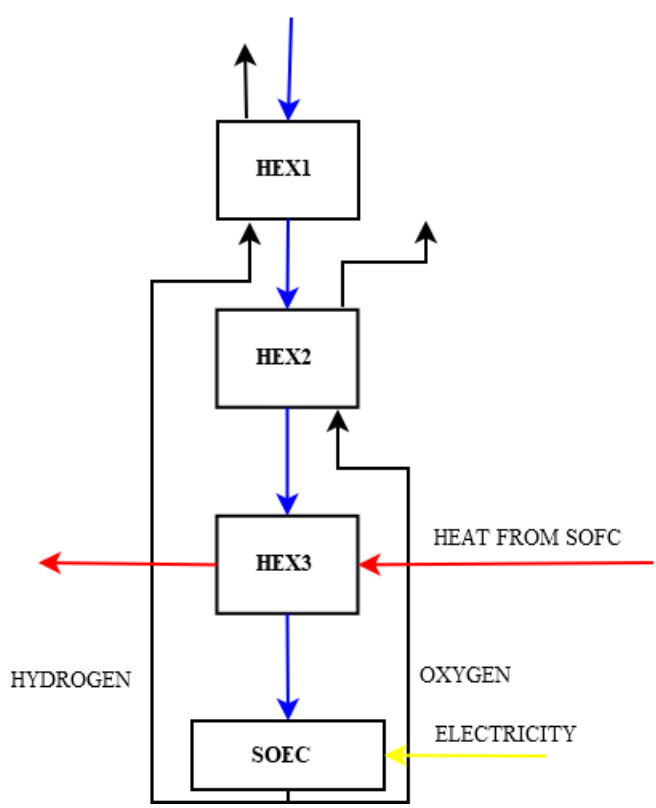

Figure 8-SOEC system layout. Water (blue line) is heated by using product gases (black lines, hydrogen and oxygen) and exhaust gases from SOFC (red line), in order to obtain steam at operating temperature by means of heat exchangers (HEX1, HEX2 and HEX3). Electricity (yellow line) is needed to perform electrolysis in the SOEC stack.

\begin{tabular}{|l|r|}
\hline \multicolumn{1}{|c|}{ Parameter } & \multicolumn{1}{c|}{ Value } \\
\hline Stack nominal electric power & $100 \mathrm{~kW}$ \\
\hline $\begin{array}{l}\text { Hydrogen flow (at } 90 \% \text { of nominal } \\
\text { electric power) }\end{array}$ & $2.63 \mathrm{~kg} / \mathrm{h}$ \\
\hline $\begin{array}{l}\text { Heat request from SOEC (at } 90 \% \text { of } \\
\text { nominal electric power) }\end{array}$ & $15 \mathrm{~kW}$ \\
\hline Working temperature & $750{ }^{\circ} \mathrm{C}$ \\
\hline Working pressure & $7.01 \mathrm{bar}$ \\
\hline
\end{tabular}

Table 4 - SOEC system parameters.

\subsection{SOFC/SOEC interaction}

In the paper mill, Line 1 and Line 2 have different energy consumptions. The SOFC-SOEC system proposed here features some SOFCs that only operate for combined heat and power generation, whereas other stacks are reversible systems (reversible solid oxide cell, RSOC). RSOCs are proposed to efficiently manage energy generation: they can be used to generation electricity and steam when both production lines are in operation, whereas they can produce hydrogen (working as SOEC) when only one line works and the energy request is lower. The focus is on the system performance and efficiency improvements at system level, so the analysis mostly look at overall values. In particular, here the term 'RSOC' refers to the difference between SOFC generation and SOEC consumption, i.e. the net effect of the set of the cells, as seen from the industrial facility.

The aim is to vary the heat-to-power ratio of the system (i.e., the ratio between heat and electricity generated by the system, $H / P$ ) by varying the proportion between the stacks used as SOFC and the ones operating as SOEC, in order to match the energy profiles of the paper mill at supply and demand sides. If only SOFCs are used, the $\mathrm{H} / \mathrm{P}$ ratio of the system $\left((H / P)_{R S O C}\right)$ is equal to the $\mathrm{H} / \mathrm{P}$ of 
a SOFC. Instead, if a combination of SOFCs and SOECs are used, a part of the electricity and heat generated by SOFCs is consumed by SOECs to electrolyse water, and convert it into hydrogen and oxygen. The higher the fraction of SOEC, the higher the difference between $(H / P)_{R S O C}$ and $H / P$ of a SOFC-only system. Table 5 defines the variables of the system, where the subscripts SOFC, SOEC, and RSOC refers to SOFC, SOEC, and RSOC system, respectively. For the sake of clarity, each variable is also represented in Figure 10, which shows the structure of the novel system.

\begin{tabular}{|c|l|}
\hline VARIABLE & \\
\hline$H_{R S O C}$ & Heat production of RSOC system \\
\hline$P_{R S O C}$ & Electricity production of RSOC system \\
\hline$(H / P)_{R S O C}$ & Heat to power ratio of RSOC system \\
\hline$n_{R S O C}$ & Ratio between electricity consumption of SOEC and electricity production of SOFC \\
\hline$P_{M A X, R S O C}$ & Sum of both electric power of SOFC and electric power of SOEC \\
\hline$H_{S O F C}$ & Heat production of SOFC system \\
\hline$P_{S O F C}$ & Electricity production of SOFC system \\
\hline$(H / P)_{S O F C}$ & Heat to power ratio of SOFC system \\
\hline$H_{S O E C}$ & Heat consumption of SOEC system \\
\hline$P_{S O E C}$ & Electricity consumption of SOEC system \\
\hline$(H / P)_{S O E C}$ & Heat to power ratio of SOEC system consumption \\
\hline
\end{tabular}

Table 5 - List of RSOC, SOFC and SOEC variables in order to define the mutual interaction.

\subsubsection{Mathematical model}

$n_{R S O C}$ is defined as the ratio between SOEC electricity consumption $\left(P_{S O E C}\right)$ and SOFC electricity generation $\left(P_{S O F C}\right)$, as presented in Equation 4.

$$
n_{R S O C}=\frac{P_{S O E C}}{P_{S O F C}}
$$

$H_{R S O C}$ and $P_{R S O C}$ are the heat and electricity generation of the overall system, respectively. These variables are defined as the difference between SOFC generation and SOEC consumption in terms of heat (Equation 5) and electricity (Equation 6), respectively.

$$
\begin{aligned}
& H_{R S O C}=H_{S O F C}-H_{S O E C} \\
& P_{R S O C}=P_{S O F C}-P_{S O E C}
\end{aligned}
$$

$n_{R S O C}$ relates $(H / P)_{R S O C},(H / P)_{S O F C}$ and $(H / P)_{S O E C}$. Equation (7) defines the heat-to-power ratio of RSOC system considering Equations (5) and (6). So, an expression that only uses H/P ratios as variables is obtained (Equation (10)) if the definition from Equation (4) is used to relate electricity consumption of SOEC and electricity production of SOFC.

$$
\begin{gathered}
\left(\frac{H}{P}\right)_{R S O C}=\frac{H_{S O F C}-H_{S O E C}}{P_{S O F C}-P_{S O E C}} \\
\left(\frac{H}{P}\right)_{R S O C}=\frac{\left(\frac{H}{P}\right)_{S O F C} * P_{S O F C}-\left(\frac{H}{P}\right)_{S O E C} * P_{S O E C}}{P_{S O F C}-P_{S O E C}}
\end{gathered}
$$




$$
\begin{array}{r}
\left(\frac{H}{P}\right)_{R S O C}=\frac{\left(\frac{H}{P}\right)_{S O F C}-\left(\frac{H}{P}\right) S O E C * \frac{P_{S O E C}}{P_{S O F C}}}{1-\frac{P_{S O E C}}{P_{S O F C}}} \\
\left(\frac{H}{P}\right)_{R S O C}=\frac{\left.\left(\frac{H}{P}\right) S_{S O F C}-\left(\frac{H}{P}\right)\right)_{S O E C} * n_{R S O C}}{1-n_{R S O C}}
\end{array}
$$

Equation (11) defines $n_{R S O C}$ directly from $(H / P)_{R S O C},(H / P)_{S O F C}$ and $(H / P)_{S O E C}$ as

$$
n_{R S O C}=\frac{\left(\frac{H}{P}\right)_{R S O C}-\left(\frac{H}{P}\right)_{S O F C}}{\left(\frac{H}{P}\right)_{R S O C}-\left(\frac{H}{P}\right)_{S O E C}}
$$

Figure 9 shows how the heat-to-power ratio of RSOC system $\left((H / P)_{R S O C}\right)$ varies with $n_{R S O C}$. SOEC consumes electricity and heat to electrolyse water, and energy is provided by SOFC: the higher the SOEC utilisation, the lower the electricity and heat available from SOFC to the paper production lines. $(H / P)_{R S O C}$ represents the ratio between electricity and heat available from the RSOC system: the higher the fraction of stacks operating as SOEC, the higher the $(H / P)_{R S O C}(H / P)_{R S O C}$ increases when the proportion shifts towards SOEC presence, because SOEC consumes proportionally more electricity than heat from SOFC. $n_{R S O C}$ is useful to analyse how to match $(H / P)_{S O F C}$ and heat-topower ratio required by the user (production lines) $(H / P)_{\text {USER }}$ if $(H / P)_{\text {USER }}$ is higher than $(H / P)_{S O F C}$, an increase of SOEC utilisation is needed to increase $(H / P)_{R S O C}$. In this study, the authors propose a RSOC system with the possibility of varying $(H / P)_{R S O C}$ by means of hydrogen production. As a matter of fact, a larger number of devices to match $(H / P)_{U S E R}$ is in operation, while using the overgeneration to produce an additional good instead of relying power on the grid. Indeed, if $(H / P)_{R S O C}$ and $(H / P)_{\text {USER }}$ did not match, withdrawn of heat from some kind of storage, steam generation via natural gas-fired boiler, or electricity exchange with the power grid would occur to overcome the mismatching between local energy generation and consumption (heat and/or electricity).

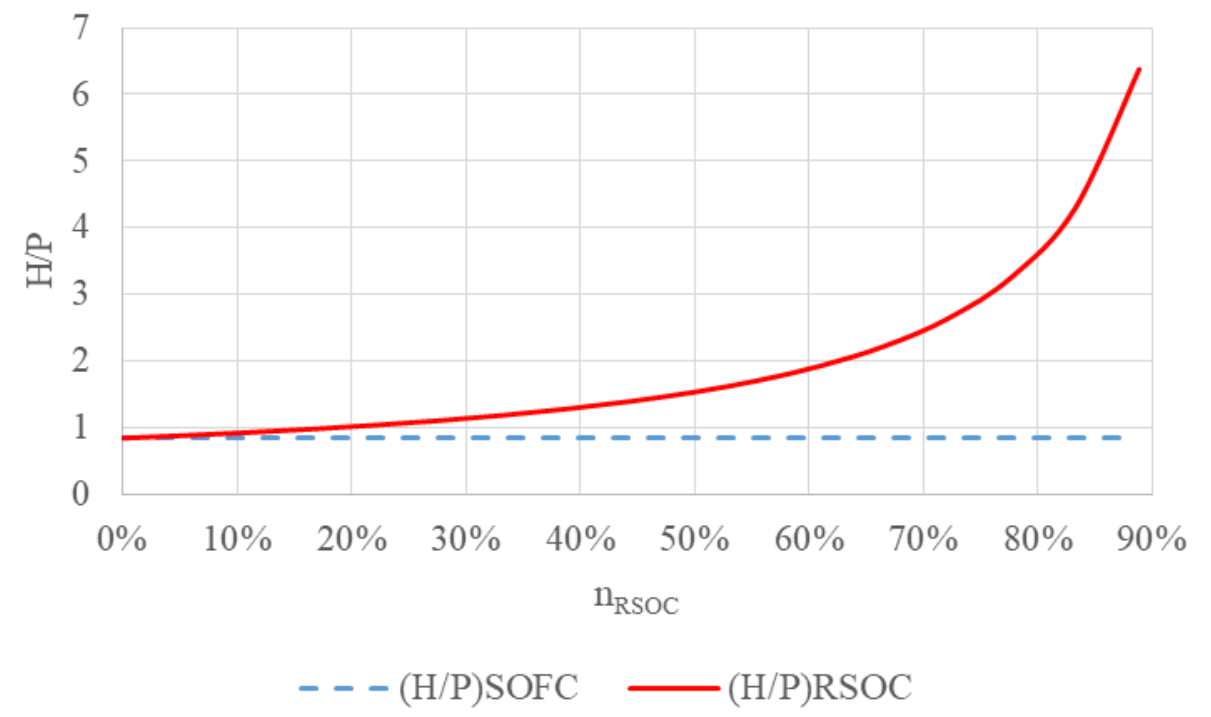

Figure $9-R S O C$ system heat to power ratio versus $n_{R S O C}$

Given $P_{R S O C}$, which is known because it is the electricity required by the paper production lines from the RSOC system, $P_{S O F C}$ and $P_{S O E C}$ can be defined through $n_{R S O C}$. In particular, considering Equations (4) and (6), $P_{S O F C}$ and $P_{S O E C}$ can be obtained by Equation (12) and (13), respectively: 


$$
\begin{aligned}
& P_{S O F C}=\frac{1}{1-n_{R S O C}} * P_{R S O C} \\
& P_{S O E C}=\frac{n_{R S O C}}{1-n_{R S O C}} * P_{R S O C}
\end{aligned}
$$

As RSOC system is proposed, it is necessary to know the nominal power of both SOFC and SOEC. A reversible stack (RSOC) could be used either on energy generation (SOFC mode) or on hydrogen production (SOEC mode). The parameter $P_{M A X, R S O C}$ is defined as the sum of SOFC electric generation and SOEC electric consumption, so the maximum electric power of the RSOC system can be calculated (Equation 14) and, consequently, the number of stack required is defined:

$$
P_{M A X, R S O C}=P_{S O F C}+P_{S O E C}
$$

Equation (15) combines Equations (12), (13) and (14) in order to obtain $P_{M A X, R S O C}$ (maximum electric power of RSOC), by relating $n_{R S O C}$ (ratio between SOEC and SOFC) and $P_{R S O C}$ (electricity production of RSOC system).

$$
P_{M A X, R S O C}=\frac{1+n_{R S O C}}{1-n_{R S O C}} * P_{R S O C}
$$

Equations (11) and (15) are useful to size the RSOC system, which is the novel element proposed in this study. In particular:

1. $(H / P)_{R S O C}$ and $P_{R S O C}$ are known due to energy request of the user, while $(H / P)_{S O F C}$ and $(H / P)_{S O E C}$ are gathered from technical datasheet and/or simulation; Equation (11) then defines the ratio between SOEC and SOFC power $\left(n_{R S O C}\right)$ by using these parameters;

2. Equation (15) defines the size of the RSOC system $\left(P_{M A X, R S O C}\right)$ and, consequently, the number of stacks as a function of the ratio between SOEC and SOFC $\left(n_{R S O C}\right)$, and electricity generation of RSOC system $\left(P_{R S O C}\right)$.

\section{NOVEL SYSTEM SIMULATION}

As mentioned in section 3, the novel system uses RSOC to generate both electricity and heat for the paper production lines so that it is possible to remove the highest-power steam turbine. Figure 10 represents the novel system proposed with the scheme of the energy flows. 


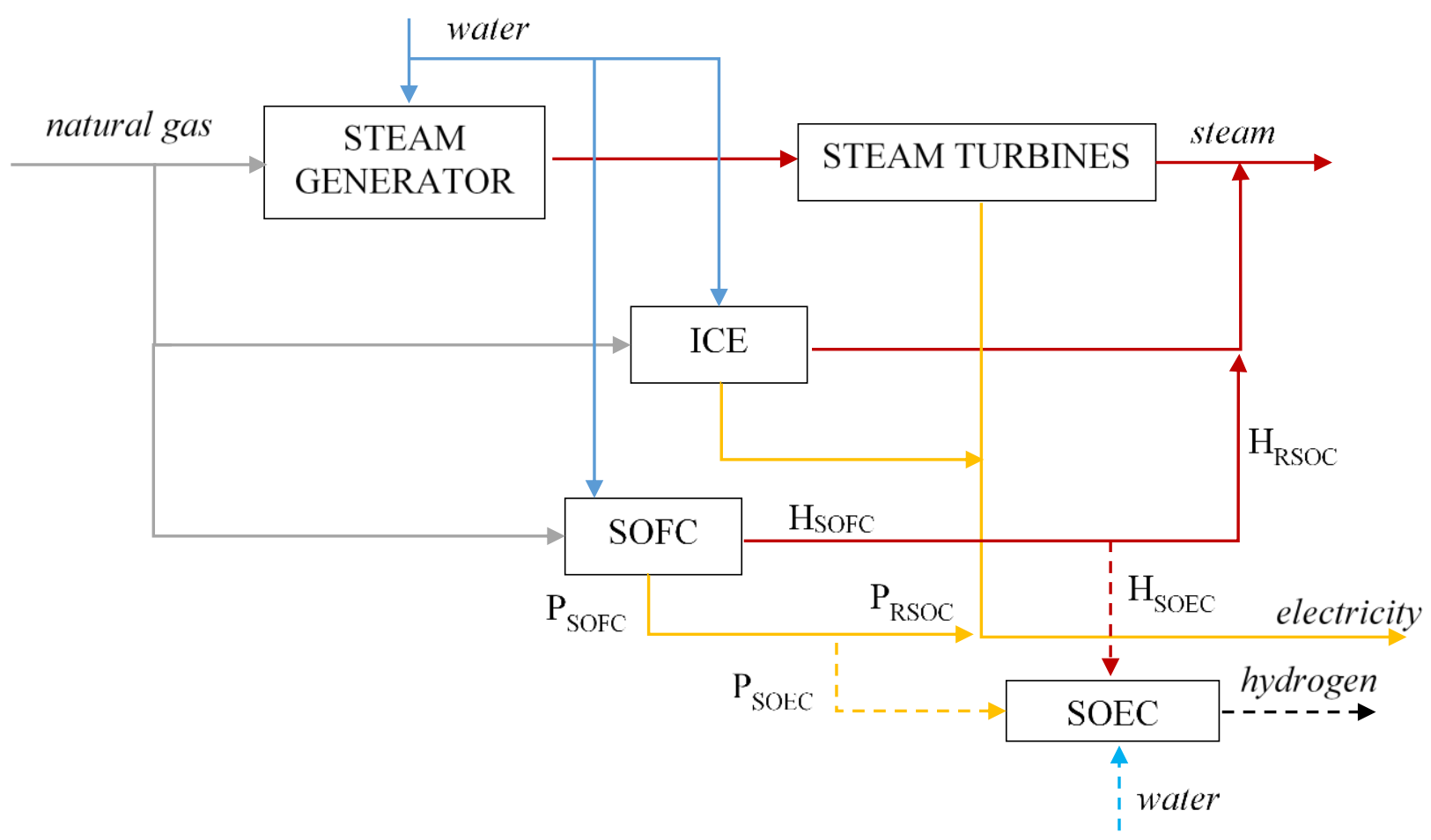

Figure 10-Overview of the novel system. Grey flow is natural gas, blue flow is water, red flow is steam, yellow lines are electricity, and black lines are hydrogen. Inlet water of SOEC is an independent circuit with respect to water for steam production

\subsection{Operation of the novel system}

The main goals of the proposed revamping of the cogeneration plant are:

- to increase the efficiency of energy generation system of the industrial facility;

- to cast off the old and low-efficiency steam turbines;

- to produce hydrogen by SOECs during periods of mismatched heat-to-power ratio between the user request $\left((H / P)_{U S E R}\right)$ and the possible SOFC-only generation $\left((H / P)_{S O F C}\right)$, achieving the equality by varying the ratio between RSOC working as SOFC and RSOC working as SOEC.

In order to size each component, the case with the highest energy consumption (Case 1+2) is considered. Some constraints are considered:

A. the current generation system will be upgraded gradually, and not entirely dismissed. SOFCs are thought to be adopted to decrease the amount of electricity produced by the oldest component, so with low efficiency, of the system (steam turbine);

B. the existing ICE has better performance than the steam turbines, and it currently works with a base-load strategy. Steam turbines, instead, work as an additional system to cover heat demand. A similar strategy is proposed for the novel system: ICE will work as base load, while SOFCs, and possibly one of the two steam turbines, will work as additional generation system.

In the present study, the following assumptions are considered:

- RSOC is used only in SOFC mode due to high electricity consumption;

- only Turbine 1 is used in order to dismiss the highest-power one (Turbine 2), constraint A; 
- ICE, steam turbine, and RSOC cover heat and electricity consumption without any integration from grid;

- ICE electricity production is maximised (constraint B).

A system of equations (16) describes energy flows and interactions between steam turbine, ICE and RSOC. Electricity $\left(P_{U S E R}\right)$ and heat $\left(H_{U S E R}\right)$ consumptions of the user are covered by steam turbines cogeneration system (respectively $P_{S T}$ and $H_{S T}$ ), ICE $\left(P_{I C E}\right.$ and $\left.H_{I C E}\right)$, and the part of RSOC working in SOFC-only mode $\left(P_{S O F C}\right.$ and $\left.H_{S O F C}\right)$. Heat-to-power ratio of each component of the system (steam turbine $f_{S T, H / P}$, ICE $f_{I C E, H / P}$, and SOFC $\left.f_{S O F C, H / P}\right)$ is defined as constraint, imposing the lower power limits of ICE, steam turbine and SOFC. The steam flow rate varies between $5 \mathrm{ton} / \mathrm{h}$ and 21 ton/h, as mentioned in Table 1. Among the solutions of the system, one is selected by solving as an optimisation problem: maximise electricity production of ICE $\left(P_{I C E}\right)$ (constraint B).

$$
\max \left(P_{I C E}\right) \text { s.t. }\left\{\begin{array}{c}
P_{I C E}+P_{S T}+P_{S O F C}=P_{U S E R} \\
H_{I C E}+H_{S T}+H_{S O F C}=H_{U S E R} \\
H_{I C E}-P_{I C E} * f_{I C E, \frac{H}{P}}=0 \\
H_{S T}-P_{S T} * f_{S T, \frac{H}{P}}=0 \\
H_{S O F C}-P_{S O F C} * f_{S O F C, \frac{H}{P}}=0 \\
5<\dot{m}_{S t e a m}<21 \\
P_{I C E}>0 \\
P_{S T}>0 \\
P_{S O F C}>0
\end{array}\right.
$$

As previously mentioned, Case $1+2$ has the highest energy consumption because both Line 1 and Line 2 work simultaneously. Since this is the scenario with the highest energy consumption, it is assumed that $P_{S O F C}$ proposed as solution of this system is, also, the maximum electric power of the RSOC system installed ( $\left.P_{\text {RSOC installed }}\right)$. In other cases, RSOC system can work partly in SOFC mode, partly in SOEC mode. A constraint is added: the sum of electric power of the cells working as SOFC and as SOEC must be lower or equal than $P_{\text {RSOC installed. }}$

A new system of equations (17) describes the novel system when Line 1 or Line 2 works separately (respectively Case 1 and Case 2). In these cases, less energy (both electricity and heat) is required, so a part of RSOCs is used as SOECs to produce hydrogen. The energy consumption of SOEC ( $P_{S O E C}$ and $H_{S O E C}$ for electricity and heat respectively), the equation of heat-to-power ratio of SOEC, and constraint on electric power of SOFC and SOEC (RSOC system) are considered in Equation (17). Similarly to equation (16), maximisation of ICE electricity production $\left(P_{I C E}\right)$ is imposed. 


$$
\max \left(P_{I C E}\right) \text { s.t. }\left\{\begin{array}{c}
P_{I C E}+P_{S T}+P_{S O F C}=P_{U S E R}+P_{S O E C} \\
H_{I C E}+H_{S T}+H_{S O F C}=H_{U S E R}+H_{S O E C} \\
H_{I C E}-P_{I C E} * f_{I C E, \frac{H}{P}}=0 \\
H_{S T}-P_{S T} * f_{S T, \frac{H}{P}}=0 \\
H_{S O F C}-P_{S O F C} * f_{S O F C, \frac{H}{P}}=0 \\
H_{S O E C}-P_{S O E C} * f_{S O E C, \frac{H}{P}}=0 \\
5<\dot{m}_{S t e a m}<21 \\
P_{I C E}>0 \\
P_{S T}>0 \\
P_{S O F C}+P_{S O E C} \leq P_{R S O C \text { installed }}
\end{array}\right.
$$

Results of equations (16) and (17) of the novel system are reported in Table 6. It is possible to cast off turbine 2 (the highest power one) because the availability of steam from SOFC decreases the steam flow rate to be processed by steam turbine. Adoption of RSOC system allows matching $H / P$ ratio of energy production and $H / P$ of energy consumption. RSOC system produces hydrogen when only one line operates. Simulations show that electricity consumption from the grid is avoided, making the system grid independent.

\begin{tabular}{|c|c|c|c|c|c|c|c|}
\hline \multirow[b]{2}{*}{ CASES } & \multicolumn{3}{|c|}{ CURRENT SYSTEM } & \multicolumn{4}{|c|}{ INNOVATIVE SYSTEM } \\
\hline & $\begin{array}{c}\text { ICE (\% } \\
\text { nominal } \\
\text { load })\end{array}$ & $\begin{array}{l}\text { Operating } \\
\text { turbine }\end{array}$ & $\begin{array}{c}\text { Turbine } \\
\text { steam flow } \\
\text { rate }\end{array}$ & $\begin{array}{c}\text { ICE (\% } \\
\text { nominal } \\
\text { load })\end{array}$ & $\begin{array}{l}\text { Turbine steam } \\
\text { flow rate }\end{array}$ & SOFC & SOEC \\
\hline CASE 1 & $100 \%$ & Turbine 1 & 12.8 ton $/ \mathrm{h}$ & $60 \%$ & 11.38 ton $/ \mathrm{h}$ & $2.448 \mathrm{MW}$ & $576 \mathrm{~kW}$ \\
\hline CASE 2 & $100 \%$ & Turbine 1 & 8.8 ton $/ \mathrm{h}$ & $100 \%$ & 6.04 ton $/ \mathrm{h}$ & $2.595 \mathrm{MW}$ & $551 \mathrm{~kW}$ \\
\hline CASE $1+2$ & $100 \%$ & Turbine 2 & 24.8 ton $/ \mathrm{h}$ & $100 \%$ & 20.68 ton $/ \mathrm{h}$ & $3.259 \mathrm{MW}$ & - \\
\hline
\end{tabular}

Table 6 - Working parameter of ICE (\% partial load), steam turbine (steam flow), SOFC and SOEC electric power.

\subsection{Primary Energy Saving}

This section presents a thermodynamic analysis comparing the current and the novel system. The analysis calculates energy flows, and estimates primary energy $(P E)$ consumption in each cases. Primary energy consumption is proposed as a benchmark: for each case (Case 1, Case 2 and Case $1+2)$, primary energy saving $(P E S)$ between the current and the novel systems is determined (Equation 18). Primary energy of the existing system ( $\left.P E_{\text {current sys. }}\right)$ is a function of natural gas

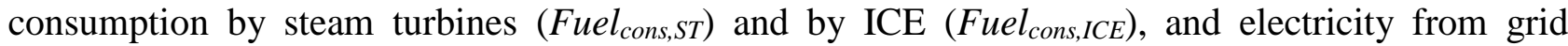
$\left(E_{\text {grid }}\right)$. Primary energy of the novel system $\left(P E_{\text {novel sys. }}\right)$ is a function of natural gas consumption by

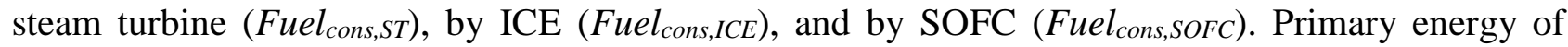
natural gas is expressed by LHV, whereas electricity consumptions are converted to primary energy by no-renewable primary factor $f_{p, n r e n}=1.95$ according to Italian standard DM 26/06/2015 (corresponding to an efficiency $\eta_{\text {grid }}$ equal to 0.513 ). If hydrogen is produced, its primary energy is expressed by LHV, and is subtracted from the energy consumption of the energy system because it is considered to be used as fuel within the system. 


$$
P E S=1-\frac{P E_{\text {novel sys. }}}{P E_{\text {current sys. }}}=1-\frac{\text { Fuel }_{\text {cons }, S T}+\text { Fuel }_{\text {cons }, I C E}+F u e l_{\text {cons }, \text { SOFC }}-F u e l_{H 2}}{\text { Fuel }_{\text {cons }, S T}+F u e l_{\text {cons }, I C E}+\frac{E_{\text {grid }}}{\eta_{\text {grid }}}}
$$

Calculations show that the novel system presents a primary energy saving in all cases. Table 7 summarizes the results: Case 1 and Case 2 have lower PES, while hydrogen is produced. Instead, Case $1+2$ does not have hydrogen production (RSOC is used only in SOFC mode due to the higher energy request), and it has the highest efficiency. In fact, SOFC and PES (considering also Table 6) are related: the higher SOFC nominal power, the higher PES.

\begin{tabular}{|l|c|c|}
\hline \multicolumn{1}{|c|}{ CASE } & HYDROGEN PRODUCTION & PES \\
\hline Case 1 & $16.857 \mathrm{~kg} / \mathrm{h}$ & $2.7 \%$ \\
\hline Case 2 & $16.137 \mathrm{~kg} / \mathrm{h}$ & $2.3 \%$ \\
\hline Case $1+2$ & - & $6.5 \%$ \\
\hline \multicolumn{2}{|c|}{ Table $7-$ Primary energy saving values for each analysed case. }
\end{tabular}

\subsection{Hydrogen generation performance}

Results of section 4.2 demonstrates that primary energy savings can occur with respect to current system, whereas the complexity of the novel system with hydrogen production is increased. In this section, focusing on hydrogen only, an estimation of the primary energy saving obtained with the production of hydrogen within the novel system with respect to a more established alternative that uses PEM electrolysers (PEMEC) is proposed.

In general, SOEC systems have higher efficiency on hydrogen production compared to other technologies (e.g., PEM electrolysis), thanks to the thermodynamically more favourable operating conditions. However, they require heat at high temperature, which might not be easily available.

In the paper mill application, when the industrial facility operates at partial load (i.e., only one paper production lines works); the energy generation system operation also changes: a part of the RSOC units works as SOFC, and a part works as SOEC, thus determining a net hydrogen output. Looking at Figure 11, SOEC uses energy (both electricity and heat) generated only by some of the units in the RSOC system that work as SOFC. SOEC requires heat at high temperature $\left(750{ }^{\circ} \mathrm{C}\right.$, Table 4) which SOFC could provide by means of heat recovery while generating electricity. As SOEC has a proportionally lower heat consumption than electricity compared to the $H / P$ ratio of SOFC generation (Table 4$)$, a part of the SOFC heat generation $\left(\mathrm{H}_{\mathrm{SOFC}}\right)$ is used for SOEC $\left(H_{S O E C}\right)$, and a part is used to produce steam $\left(H_{S O F C}-H_{S O E C}\right)$. Figure 11 details the energy flows for the hydrogengenerating section of the SOFC-SOEC system. 


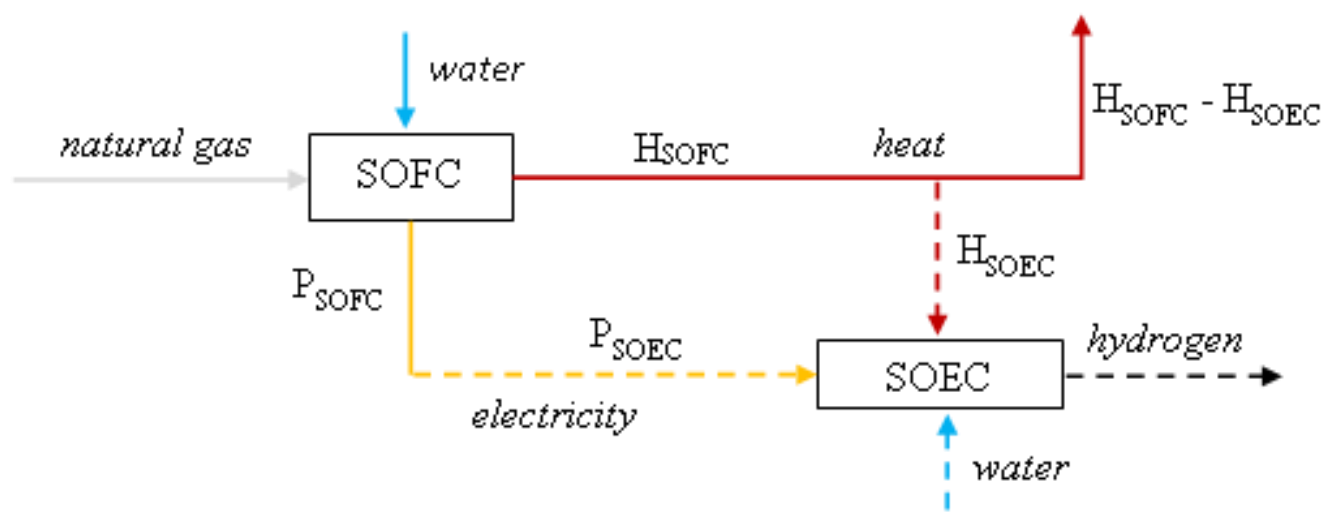

Figure 11 - Section of RSOC system used to produce hydrogen. Electricity required by SOEC is provided by SOFC, with no excess $\left(P_{S O F C}=P_{S O E C}\right) ;$ meanwhile a part of the heat $\left(H_{S O F C}-H_{S O E C}\right)$ produces steam for industrial needs.

Equation (19) describes primary energy saving on hydrogen generation $\left(P E S_{H 2}\right.$ gen $)$. The primary energy consumption by the novel system ( $P E_{H 2}$ novel sys $)$ corresponds to the natural gas consumed by

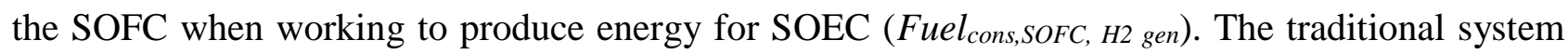
consumes primary energy ( $P E_{H 2}$ trad sys $)$ to produce hydrogen by a PEM electrolysis cell, considering that the electricity consumed $\left(E_{P E M E C}\right)$ is taken from the grid ( $\eta_{\text {grid }}$, as previous mentioned, is fixed at 0.513 ). Efficiency on hydrogen production by the PEM electrolyser is fixed at $48 \mathrm{kWh}_{\mathrm{e}} / \mathrm{kg}_{\mathrm{H} 2}$ as proposed in [32] for 2020. Finally, to consistently compare the two systems considering the same total output, it is supposed that the traditional system uses a natural gas boiler (efficiency $\eta_{\text {boiler }}$ equal to 0.9 ) to generate the heat for industrial uses (i.e., the thermal power that is not consumed by $\mathrm{SOEC}$ in the novel system, represented by the variable $\left(\mathrm{H}_{\mathrm{SOFC}}-\mathrm{H}_{\mathrm{SOEC}}\right)$ in Figure 11$)$.

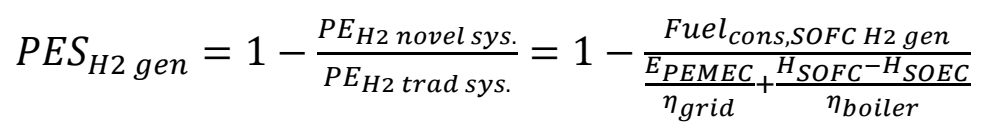

The comparison only analyses case 1 and case 2 among the paper mill operating configurations, as partial operation of the paper production lines is a necessary condition for net hydrogen production to occur (see Section 2 and 3). Equation (19) supplies the primary energy savings, which are reported in Table 8. In Case 1 and Case 2, values of $P E S_{H 2}$ gen show around $45 \%$ reduction of primary energy consumption with the use of the integrated SOFC-SOEC system. Case 1+2, instead, has no hydrogen production, because RSOC is used only in SOFC mode.

\begin{tabular}{|c|c|c|c|c|c|}
\hline CASE & H $_{2}$ PRODUCTION & $\begin{array}{c}\text { Fuel consumption, } \\
\text { SOFC }\end{array}$ & EPEMEC & H $_{\text {SOFC-H }}$ SOEC & PES $_{\text {H } \text { gen }}$ \\
\hline Case 1 & $16.857 \mathrm{~kg} / \mathrm{h}$ & $1.09 \mathrm{MW}$ & $1.86 \mathrm{MW}$ & $0.39 \mathrm{MW}$ & $45.6 \%$ \\
\hline Case 2 & $16.137 \mathrm{~kg} / \mathrm{h}$ & $1.05 \mathrm{MW}$ & $1.78 \mathrm{MW}$ & $0.36 \mathrm{MW}$ & $45.3 \%$ \\
\hline Case $1+2$ & - & - & - & - & - \\
\hline
\end{tabular}

Table 8 - Primary energy saving on hydrogen generation

\subsection{Hydrogen cost}


The aim of the system revamping is not only to save primary energy for the industrial heat and power consumption, but also to introduce a hydrogen production that could be profitable at a reasonable cost. To evaluate the economics of the hydrogen production in the novel system, the RSOC integrated solution is compared to a simpler alternative based on PEMEC. It is considered, also, that when a RSOC system is used, products are both hydrogen and heat for industrial use (Figure 11). Hence, the PEMEC system must be coupled to a steam generator, which is assumed to be a natural gas-fired boiler with efficiency equal to 0.90 , to offer the same output. The analysis assumes to feed the PEMEC with grid electricity.

The cost analysis first calculates the equivalent annual cost $(E A C)$, then divides it by annual hydrogen production to obtain the fuel cost. EAC (Equation 20) depends on net present value (NPV) and annuity factor $\left(A_{t, i}\right)$ :

$$
E A C=\frac{N P V}{A_{t, i}}(20)
$$

The NPV here considered includes investment costs (purchase costs of the components), annual energy consumption costs, and annual maintenance costs (considering inflation rate). Purchase and maintenance costs of RSOC and PEMEC are estimated according to [32] referring to 2020 scenario. RSOC is still a developing technology, so the cost is a forecast and it is likely subject to variation. To take into account this uncertainty, a sensitivity analysis on the RSOC purchase cost is performed, comprising a range between $-10 \%$ and $+30 \%$ of the proposed cost. It is considered, also, that the RSOC system integrated in the paper mill produces hydrogen only during $2 / 3$ of the total time, while for $1 / 3$ its components are used in SOFC-only mode (Table 6). Therefore, investment cost is proportionally allocated to the output, and only $2 / 3$ of it affect the hydrogen economics. Variable cost for energy input in terms of electricity and gas are given by [33] and [34], respectively. Moreover, each of them has an annual increasing index, calculated as the average cost variation over the last 4 years. As previously mentioned, heat is available and used to produce steam in the RSOC system, while the PEMEC system uses a natural gas-fired boiler to generate the steam: in this case, only natural gas consumption is considered. Annuity factor is defined by the expected lifetime of the system (assumed equal to 10 years) and by an interest rate of $4 \%$.

\begin{tabular}{|l|c|}
\hline \multicolumn{1}{|c|}{ PARAMETER } & VALUE \\
\hline Purchase cost RSOC & $2000 € / \mathrm{kW}$ \\
\hline Purchase cost PEM & $1000 € / \mathrm{kW}$ \\
\hline Maintenance cost RSOC/PEM & $5 \%$ \\
\hline Natural gas cost & $0.0237 € / \mathrm{kWh}$ \\
\hline Natural gas increasing index & $-0.031 \%$ \\
\hline Electricity cost & $0.1436 € / \mathrm{kWh}$ \\
\hline Electricity increasing index & $-0.059 \%$ \\
\hline Expected lifetime RSOC/PEM & 10 year \\
\hline Interest rate & $4 \%$ \\
\hline Inflation rate & $2 \%$ \\
\hline \multicolumn{2}{|c|}{ Table $9-$ Economic parameter of the analysis }
\end{tabular}


Figure 12 represents the results in terms of hydrogen cost, as a function of the variation of RSOC purchase cost with respect to the forecasted value. In the whole range considered, the RSOC system has a lower cost on hydrogen production then the PEMEC system. Hydrogen cost varies between $6 € / \mathrm{kg}$ and $8 € / \mathrm{kg}$, while it is equal to $10 € / \mathrm{kg}$ with a PEMEC. This reflects the high efficiency of RSOC in both SOEC and SOFC operation, and the availability of heat from the RSOC system energy balances that is used to generate steam for the industrial facility. On the opposite, the PEMEC system has a separate unit for steam generation, thus excluding any synergy. Moreover, the lower electricity-to-hydrogen efficiency is affected by the high price of electricity compared to natural gas.

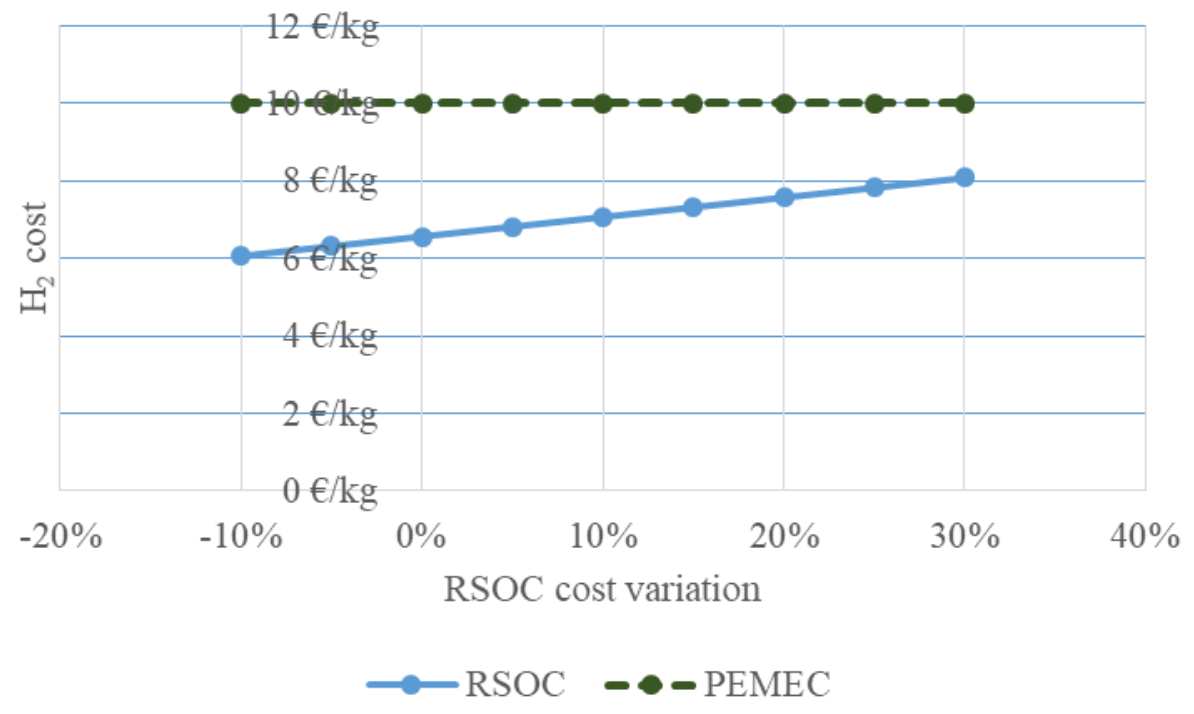

Figure 12 - Economic analysis of hydrogen generation cost.

\section{CONCLUSIONS}

This article proposes an innovative system for combined heat and power generation, to be used in an industrial facility (paper mill) to increase energy efficiency, while adding new business stream in the hydrogen field. The main component of the retrofit is the Reversible Solid Oxide Fuel Cell (RSOC), which can be used alternatively either as SOFC (to generate heat and electricity) or as SOEC (to produce hydrogen). The ratio between SOFC and SOEC varies with the variation of electricity and heat consumption in order to match the H/P ratios at supply and demand side.

The current system is composed by two steam turbines and an ICE, and it allows electricity withdrawn from the power grid when needed. Operational data of the system has been used to model the existing components and size the units of the innovative system. The introduction of RSOCs makes it possible to dismiss one of the low-efficient steam turbines, thus increasing the efficiency on energy generation. Simulations show that it is possible to achieve a primary energy saving up to $6 \%$ : the higher the SOFC power, the higher the achieved PES. Hydrogen is produced at a rate of $16 \mathrm{~kg} / \mathrm{h}$, but it occurs exclusively when only one paper production line is in operation. Furthermore, simulation results highlight that the RSOC system features a primary energy saving on hydrogen production in the order of $45 \%$ with respect to a traditional system based on PEM electrolysis fed with grid electricity. Economic analysis has investigated hydrogen generation cost 
in the proposed RSOC system, comparing it to the production via PEM electrolysers. In the whole range of variation of the investment cost $(-10 \%$ to $+30 \%$ of the value proposed in literature), the RSOC integrated system has lower cost for hydrogen generation.

A further development of this study could address a wider economic evaluation of the proposed retrofit, as well as an analysis of more efficient operation strategies to increase total primary energy and/or increase hydrogen integration.

\section{LIST OF ACRONYMS}

$\begin{array}{ll}\text { AP } & \text { Air Preheater } \\ \text { CHP } & \text { Combined Heat and Power } \\ \text { CP } & \text { Cathode Preheater } \\ \text { CPO } & \text { Catalytic Partial Oxidizer } \\ \text { DNA } & \text { Dynamic Network Analyser } \\ \text { EAC } & \text { Equivalent annual cost } \\ \text { FP } & \text { Fuel Preheater } \\ \text { LHV } & \text { Lower Heat Value } \\ \text { H/P } & \text { Heat-to-Power ratio } \\ \text { HEX } & \text { Heat Exchanger } \\ \text { ICE } & \text { Internal Combustion Engine } \\ \text { LHV } & \text { Lower Heating Value } \\ \text { NPV } & \text { Net present value } \\ \text { PE } & \text { Primary Energy } \\ \text { PEM } & \text { Proton Exchange Membrane } \\ \text { PEMEC } & \text { Proton Exchange Membrane Electrolysis Cell } \\ \text { PES } & \text { Primary Energy Saving } \\ \text { RP } & \text { Reformer Preheater } \\ \text { RSOC } & \text { Reversible Solid Oxide Cell } \\ \text { SOEC } & \text { Solid Oxide Electrolysis Cell } \\ \text { SOFC } & \text { Solid Oxide Fuel Cell } \\ \text { ST } & \text { Steam Turbine }\end{array}$

NOMENCLATURE

$\mathrm{A}_{\mathrm{t}, \mathrm{i}}$

Egrid

EPEMEC

Fuel $_{\text {cons,ICE }}$

Fuel $_{\text {cons,ST }}$

Fuel $_{\text {cons,SOFC }}$

$\mathrm{f}_{\mathrm{ICE}, \mathrm{H} / \mathrm{P}}$

$\mathrm{f}_{\mathrm{p} \text {,nren }}$

$\mathrm{f}_{\mathrm{ST}, \mathrm{H} / \mathrm{P}}$

$\mathrm{f}_{\mathrm{SOFC}, \mathrm{H} / \mathrm{P}}$

$\mathrm{f}_{\mathrm{SOEC}, \mathrm{H} / \mathrm{P}}$

HICE
Annuity factor

Electricity consumption from grid

Fuel consumption, SOFC

$\mathrm{H} / \mathrm{P}$ ratio of ICE

no-renewable primary factor

$\mathrm{H} / \mathrm{P}$ ratio of steam turbine

$\mathrm{H} / \mathrm{P}$ ratio of SOFC

$\mathrm{H} / \mathrm{P}$ ratio of SOEC

Heat production of the ICE
(W) 


\begin{tabular}{|c|c|c|}
\hline $\mathrm{H}_{\mathrm{RSOC}}$ & Heat production of RSOC system & $(\mathrm{W})$ \\
\hline $\mathrm{H}_{\text {SOEC }}$ & Heat consumption of SOEC & $(\mathrm{W})$ \\
\hline $\mathrm{H}_{\text {SOFC }}$ & Heat production of SOFC & $(\mathrm{W})$ \\
\hline $\mathrm{H}_{\mathrm{ST}}$ & Heat production of the steam turbine & $(\mathrm{W})$ \\
\hline HUSER & Heat consumptions of the user & $(\mathrm{W})$ \\
\hline$(\mathrm{H} / \mathrm{P})_{\mathrm{SOEC}}$ & Heat to power ratio of SOEC consumption & \\
\hline$(\mathrm{H} / \mathrm{P})_{\mathrm{SOFC}}$ & Heat to power ratio of SOFC & \\
\hline$(\mathrm{H} / \mathrm{P})_{\mathrm{RSOC}}$ & Heat to power ratio of RSOC system & \\
\hline$\dot{\mathrm{m}}_{\text {steam }}$ & Steam mass flow rate & $(\mathrm{kg} / \mathrm{s})$ \\
\hline$\eta_{\text {grid }}$ & Grid efficiency & \\
\hline $\mathrm{n}_{\text {RSOC }}$ & $\begin{array}{l}\text { Ratio between electricity consumption of } \\
\text { SOFC }\end{array}$ & nd electricity production of \\
\hline PE current sys. & Primary energy consumption of the curren & $(\mathrm{W})$ \\
\hline PE $E_{\text {novel sys. }}$ & Primary energy consumption of the novel & $(\mathrm{W})$ \\
\hline PMAX,RSOC $_{\text {MAT }}$ & Sum of both electric power of SOFC and & ower of SOEC (W) \\
\hline $\mathrm{P}_{\mathrm{ICE}}$ & Electricity production of the ICE & $(\mathrm{W})$ \\
\hline $\mathrm{P}_{\mathrm{ST}}$ & Electricity production of steam turbine & $(\mathrm{W})$ \\
\hline $\mathrm{P}_{\mathrm{RSOC}}$ & Electricity production of RSOC system & $(\mathrm{W})$ \\
\hline $\mathrm{P}_{\text {RSOC installed }}$ & RSOC installed power & $(\mathrm{W})$ \\
\hline $\mathrm{P}_{\mathrm{SOEC}}$ & Electricity consumption of SOEC & $(\mathrm{W})$ \\
\hline $\mathrm{P}_{\mathrm{SOFC}}$ & Electricity production of SOFC & $(\mathrm{W})$ \\
\hline Puser & Electricity consumption of the user & $(\mathrm{W})$ \\
\hline
\end{tabular}

\section{REFERENCES}

1. European Commission. Communication from the Commission to the European Parliament, the Council, the European Economic and Social Committee and the Committee of the Regions. A roadmap for moving to a competitive low carbon economy in 2050. 2011.

2. Nastasi B., Lo Basso G. Power-to-Gas integration in the Transition towards Future Urban Energy Systems. International Journal of Hydrogen Energy, 42(38) (2017), pp. 23933-23951. DOI: 10.1016/j.ijhydene.2017.07.149

3. Zhang X., Chan S.H., Ho H.K., Tan S.C., Li M., Li G., Li J., Feng Z. Towards a smart energy network: The roles of fuel/electrolysis cells and technological perspectives. International Journal of Hydrogen Energy, 40(21) (2015), pp. 6866-6919. DOI: 10.1016/j.ijhydene.2015.03.133

4. Oldenbroek V., Verhoef L.A., van Wijk A.J.M. Fuel cell electric vehicle as a power plant: Fully renewable integrated transport and energy system design and analysis for smart city areas. International Journal of Hydrogen Energy, 42(12) (2017), pp. 8166-8196. DOI: 10.1016/j.ijhydene.2017.01.155

5. Aden N. Necessary but not sufficient: the role of energy efficiency in industrial sector lowcarbon transformation. Energy Efficiency, 11(5) (2018), pp. 1083-1101. DOI: 10.1007/s12053017-9570-z

6. Chiaroni D., Chiesa M., Chiesa V., Franzò S., Frattini F., Toletti G. Introducing a new perspective for the economic evaluation of industrial energy efficiency technologies: An 
empirical analysis in Italy. Sustainable Energy Technologies and Assessments, 15 (2016), pp. 110. DOI: $10.1016 /$ j.seta.2016.02.004

7. Dunkelberg H., Wagner J., Hannen C., Schlüter B.A., Phan L., Hesselbach J., Lin C.-X. Optimization of the energy supply in the plastics industry to reduce the primary energy demand. Journal of Cleaner Production, 192 (2018), pp. 790-800. DOI: 10.1016/j.jclepro.2018.04.254

8. Beghi A., Lionello M., Rampazzo M. Energy-efficient management of a wood industry facility. 2017 IEEE Conference on Control Technology and Applications (CCTA). 2017. DOI: 10.1109/CCTA.2017.8062460

9. Karellas S., Giannakopoulos D., Hatzilau C.-S., Dolianitis I., Skarpetis G., Zitounis T. The potential of WHR/batch and cullet preheating for energy efficiency in the EU ETS glass industry and the related energy incentives. Energy efficiency, 11(5) (2018), pp. 1161-1175. DOI: $10.1007 / \mathrm{s} 12053-017-9587-3$

10. Siedel S., Franke M., Baumann F., Wilson H., Gromnitza U. Enhancing the energy-efficient production of tempered glass by using simulation-based optimization. 22nd IEEE International Conference on Emerging Technologies and Factory Automation (EFTA 2017). DOI: 10.1109/ETFA.2017.8247750

11. Lazzarin R., Noro M., Energy efficiency opportunities in the production process of cast iron foundries: An experience in Italy. Applied Thermal Engineering, 90 (2015), pp. 509-520. DOI: 10.1016/j.applthermaleng.2015.07.028

12. Noro M., Lazzarin R. Energy audit experiences in foundries, International Journal of Energy and Environmental Engineering, 7(4) (2016), pp. 409-423. DOI: 10.1007/s40095-014-0152-y

13. Lazzarin R., Noro M. Energy efficiency opportunities in the service plants of cast iron foundries in Italy, International Journal of Low Carbon Technologies, 12(2) (2017), pp. 96-109. DOI: 10.1093/ijlct/ctw011

14. Smolek P., Leobner I., Gourlis G., Mörzinger B., Heinzl B., Ponweiser K. Hybrid building performance simulation models for industrial energy efficiency applications. Journal of Sustainable Development of Energy, Water and Environment Systems, 6(2) (2018), pp. 381393. DOI: 10.13044/j.sdewes.d6.0194

15. Mohamed A., Hamdy M., Hasan A., Sirén K. The performance of small scale multi-generation technologies in achieving cost-optimal and zero-energy office building solutions. Applied Energy, 152 (2015), pp. 94-108. DOI: 10.1016/j.apenergy.2015.04.096

16. Palomba V., Prestipino M., Galvagno A. Tri-generation for industrial applications: Development of a simulation model for a gasification-SOFC based system. International Journal of Hydrogen Energy, 42(46) (2017), pp. 27866-27883. DOI: 10.1016/j.ijhydene.2017.06.206

17. Sun M., Wang Y., Shi L., Klemeš J.J. Uncovering energy use, carbon emissions and environmental burdens of pulp and paper industry: A systematic review and meta-analysis. Renewable and Sustainable Energy Reviews, 92 (2018), pp. 823-833. DOI: 10.1016/j.rser.2018.04.036

18. Griffin P.W., Hammond G.P., Norman J.B. Industrial decarbonization of the pulp and paper: A UK perspective. Applied Thermal Engineering, 134 (2018), pp. 152-162. DOI: 10.1016/j.applthermaleng.2018.01.126

19. Ahmadi P., Almasi A., Shahriyari M., Dincer I. Multi-objective optimization of a combined heat and power (CHP) system for heating purpose in a paper mill using evolutionary algorithm. International Journal of Energy Research, 36(1) (2012), pp. 46-63. DOI: 10.1002/er.1781 
20. D.J. Marshman, T. Chmelyk, M.S. Sidhu, R.B. Gopaluni, G.A. Dumont. Energy optimization in a pulp and paper mill cogeneration facility. Applied Energy, 87(11) (2010), pp. 3514-3525. DOI: $10.1016 /$ j.apenergy.2010.04.023

21. Henrik Holmberg, Mari Tuomaala, Turo Haikonen, Pekka Ahtila. Allocation of fuel costs and CO2-emissions to heat and power in an industrial CHP plant: Case integrated pulp and paper mill. Applied Energy, 93 (2012), pp. 614-623. DOI: 10.1016/j.apenergy.2011.11.040

22. Kenneth Möllersten, Lin Gao, Jinyue Yan, Michael Obersteiner. Efficient energy systems with $\mathrm{CO} 2$ capture and storage from renewable biomass in pulp and paper mills. Renewable Energy, 29(9) (2004), pp. 1583-1598. DOI: 10.1016/j.renene.2004.01.003

23. Shabbir I., Mirzaeian M. Feasibility analysis of different cogeneration systems for a paper mill to improve its energy efficiency. International Journal of Hydrogen Energy, 41(37) (2016), pp. 16535-16548. DOI: 10.1016/j.ijhydene.2016.05.215

24. Canan Acar, Ibrahim Dincer, Comparative assessment of hydrogen production methods from renewable and non-renewable sources, International Journal of Hydrogen Energy, 39(1) (2014), pp. 1-12, ISSN 0360-3199, DOI: 10.1016/j.ijhydene.2013.10.060

25. Astiaso Garcia D., Barbanera F., Cumo F., Di Matteo, U., Nastasi, B. Expert Opinion Analysis on Renewable Hydrogen Storage Systems Potential in Europe. Energies 2016, 9(11), 963; DOI:10.3390/en9110963

26. Guandalini G, Campanari S, Romani MC. Power-to-gas plants and gas turbines for improved wind energy dispatchability: Energy and economic assessment. Applied Energy 147 (2015), pp. 117-130. DOI: 10.1016/j.apenergy.2015.02.055

27. Beatrice Castellani, Sara Rinaldi, Elena Morini, Benedetto Nastasi, Federico Rossi, Flue gas treatment by power-to-gas integration for methane and ammonia synthesis - Energy and environmental analysis, Energy Conversion and Management, 171 (2018), pp. 626-634, ISSN 0196-8904, DOI: 10.1016/j.enconman.2018.06.025

28. Posdziech O., Schwarze K., Brabandt J. Efficient hydrogen production for industry and electricity storage via high-temperature electrolysis. International Journal of Hydrogen Energy (2018). DOI: 10.1016/j.ijhydene.2018.05.169

29. Dodds P.E., Staffell I., Hawkes A.D., Li F., Grünewald P., McDowall W., Ekins P. Hydrogen and fuel cell technologies for heating: A review. International Journal of Hydrogen Energy, 40(5) (2015), pp. 2065-2083, DOI: 10.1016/j.ijhydene.2014.11.059

30. Ullvius N. C., Rokni M., A study on a polygeneration plant based on solar power and solid oxide cells, International Journal of Hydrogen Energy, Available online 7 May 2018

31. Rokni, M. Thermodynamic Analysis of an Integrated Solid Oxide Fuel Cell Cycle with a Rankine Cycle, Energy Conversion and Management, 51(12) (2010), pp.2724-2732. DOI: 10.1016/j.enconman.2010.06.008

32. Fuel cells and hydrogen Joint undertaking, Development of Water Electrolysis in the European Union, E4tech Sàrl with Element Energy Ltd for the Fuel Cells and Hydrogen Joint Undertaking, February 2014 (available online at http://www.fch.europa.eu/)

33. "Electricity prices components for non-household consumers - annual data (from 2007 onwards) [nrg_pc_205_c]”, Eurostat (2018), accessed 21/06/2018.

http://appsso.eurostat.ec.europa.eu/nui/show.do?dataset=nrg_pc_204\&lang=en

34. “Gas prices for non-household consumers - bi-annual data (from 2007 onwards) [nrg_pc_203] ", Eurostat (2018), accessed 21/06/2018.

http://appsso.eurostat.ec.europa.eu/nui/show.do?dataset=nrg_pc_202\&lang=en 
